\title{
Mineral formation sequence in the hyperbasites of the Serovsko-Maukski ophiolite belt (the Northern Urals)
}

\author{
R.K. Ilalova \\ PhD in Geology and Mineralogy, assistant of the hystorical and dynamic geology Department, Mining \\ university, Saint-Petersburg, Russia
}

\author{
I.V. Talovina \\ Professor in Geology and Mineralogy, head of the hystorical and dynamic geology Department, Mining \\ university, Saint-Petersburg, Russia
}

\section{I.V. Vorontsovac}

PhD in Geology and Mineralogy, associate Professor of the geology and exploration of mineral deposits Department, Mining university, Saint-Petersburg, Russia

\begin{abstract}
: a comprehensive research of the geological structure and mineral composition features of the hyperbasites of the Serovsko-Maukski ophiolite belt and the weathering crust along them was carried out. Due to the complex geological history of formation of the weathering crust, a wide range of precision methods of investigation was used - optical-microscopic, $\mathrm{X}$-ray diffraction, thermal, micro-ray spectral and Raman methods. As a result, the sequence of mineral formation was revealed and the modern genetic classification of hyperbasite minerals and weathering crust was compiled. In the presented classification, all minerals of the weathering crust and hyperbasites of the Serovsko-Maukski ophiolite belt are divided into endogenous and exogenous ones. Among the endogenous ones there are four groups - magmatogenic-relikt minerals, oceanic weathering minerals, low-grade metamorphogenic-relikt and hydrothermalrelikt minerals; among the exogenous ones there are residual and infiltration-overlaid minerals. Residual minerals are divided into two subgroups - diffusion and infiltration. Thus, the results obtained allow us to identify the most important geological processes associated with the evolution of hyperbasite massifs of the Serovsko-Maukski ophiolite belt and the weathering crust along them. Moreover, the conclusions prove the appearance of hydrothermal processes and low-grade metamorphism in the history of massifs development and the weathering crust of the Serovsko-Maukski ophiolite belt, and can also be used for prediction and search for new ore nickel deposits.
\end{abstract}

\section{INTRODUCTION}

This study seems to be a topical subject because it allows us to identify the most important geological processes associated with the evolution of hyperbasite massifs of the SerovskoMaukski ophiolite belt and the weathering crust along them. And geological processes, in turn, are associated with the prediction and search for ore deposits, which also emphasize the importance of the research topic.

Aim of the research is complication of the modern genetic classification of minerals of the hyperbasites and weathering crust. Tasks of the research are: 1) to study the geological structure of hyperbasite massifs and weathering crust along them;2) to study the mineral composition of rocks of the weathering crust and hyperbasites; 3) to establish the zonation of the weathering profile; 4) to correlate the mineral composition of rocks and geological processes. 
The issue of the sequence of mineral formation of hyperbasites was first considered in the works of Ginzburg $(1946,1947,1953,1963)$. Later, some data on this issue were published by Nikitina (1956), Kukovsky (1961, 1963, 1966), Zhuravleva et al. (1971). The most recent data on the mineral composition of the weathering crust were presented in the works of Mezentseva (2011), Talovina (2012) \&Vorontsova (2013).

\section{METHODOLOGY}

During the 2015-2018 field seasons, the authors of this article carried out field work, collection of stone material, description and documentation of outcrops, ditch and well cores. A total of 150 geological sections and 500 samples of petrological differences in rocks were studied. The study of the material composition of rocks was conducted using digital technologies, which now occupy a special place in the world of science (Litvinenko, 2020; Zubov, 2017). Such as, Detection of altered rocks was carried out by means of petrographic study of transparent thin rock sections on the Leica DM2700 P microscope using domestic methods of studying these formations (400 pieces). In order to refine the diagnosis of minerals, micro-rays and Raman methods (300 definitions) were used - on the JSM-6510LA raster electron microscope with energy dispersive spectrometer JED-2200 (JEOL) in IGGD RAS (analyst O.L. Galankina) and ReactRaman 785 spectrometer (analyst E.A. Vasiliev), X-ray method (60 definitions) - on XRD 3000 TT and URD-6 X-ray diffractometers in the laboratory of the Freiberg Mining Academy (analyst R. Kleeberg), thermal method (40 definitions) - on the STA 429CD+QMS (ISC RAS, V.L. Ugolkov).

\section{RESULTS AND DISCUSSION}

The Kolskij, Ustaiskiy and Vagranskiy hyperbasite massifs $\left(\mathrm{O}_{1-2}\right)$ are located on the eastern slope of the Northern Urals and are a part of the Serovsko-Maukski ophiolite belt - the northern branch of the belt of the Urals ophiolite massifs (Vtorushin, 1969; Kononova, 1974; Vershinin, 1966). They are stretched in the meridional direction and occur among volcanogenicsedimentary formations of Middle Palaeozoic age - diabase porphyrites, tuff shales and tuff sandstones, contacting in the southwest with intrusive formations of porphyrites and quartz diorites. In the course of the Mesozoic-Cenozoic tectonic movements, the massifs were divided into large blocks and were covered by platform sediments of the Jurassic, Cretaceous and Paleogene ages. (Figure 1).

The ultramafic rocks of the massifs are almost completely serpentinized and bear the traces of intensive tectonic processing. Serpentinites are broken through by numerous dykes of basic and intermediate composition, in contact with which they are talked, chloritized and carbonated. Under the cover of the Meso-Cenozoic sediments are preserved aposerpentin rocks, which compose the ancient (T-J) weathering crust of the hyperbasites. The latter belongs to the linear-platform type and is divided into residual and transformed infiltration-metasomatic (chamosite) by genetic features. The residual crust is relict; initially it could form the lower horizons of a rather powerful primary weathering crust. During the Albian-Cenomanian period, the upper horizons of the latter were partially eroded, partially re-deposited, and underwent changes in the conditions of the recovery environment when the area was swamped and affected the laterites of $\mathrm{H}_{2} \mathrm{~S}$ и $\mathrm{CO}_{2}$ (Talovina et al., 2010; Mezentseva et al., 2011).

In the section (from bottom to top) the following zones are alternating (Table 1): 1) the zone of disintegrated serpentinite, chloritized and carbonated, weakly affected by weathering processes, 2) the zone of leached serpentinite (subjected to kerolitization, carbonation, siliconization, nontronitization, oxidation), 3) the hydration zone, 4) the oxidation zone and 5) the chamosite zone.

The mineral composition of the weathering crust of hyperbasites in the Serovsko-Maukski ophiolite belt is very complex and diverse due to the complex geological history of their formation (Stepanov et al., 2019; Aleksandrova et al., 2019; ElDeeb et al., 2019; Popov et al., 


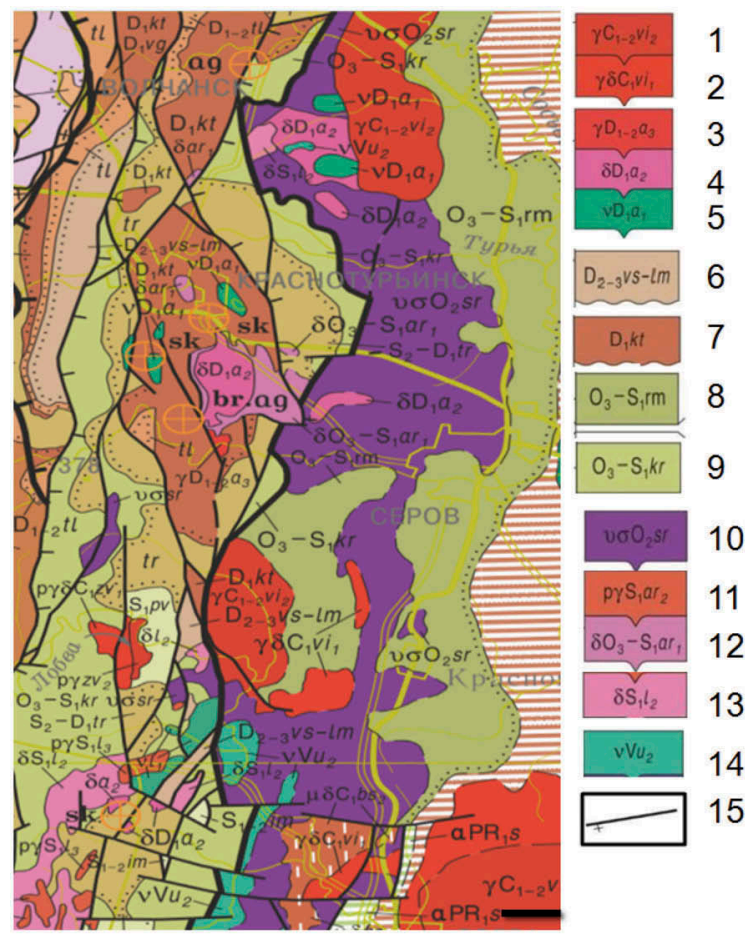

Figure 1. Geological map of the Daurian formations of the Northern Urals (A.P. Karpinsky Russian geological research institute, Uralian geological survey expedition. Map scale 1:1 000 000. Drawer: T.A. Petrova) 1-2 - Verhisetsky complex granodiorite-granite; 3-5 - Auerbach complex gabbro-diorite granite; 6 - undivided Wysotinsk and Limkin formations; 7 - Krasnoturyinsk formation; 8 - Romahinsk thick; 9 - Krasnouralsk formations; 10 - Serov complex dunite-harzburgite; 11-12 - Arbatsk complex dioriteplagiogranite; 13 - Levinsk complex gabbro-tonalit-plagiogranite; 14 - Usteysk complex dunite-verliteclinopyroxenite-gabbro; 15 - dislocations.

Table 1. Weathering profiles zoning.

\begin{tabular}{|c|c|c|c|}
\hline Weathering zone & Ongoing process & Rock varieties & Mineral varieties \\
\hline Shamosite & Shamositization & Chamosite rocks & $\begin{array}{l}\text { Chamosite, millerite-brindleyite- } \\
\text { chamosite, clinochloro-bertierine- } \\
\text { chamosite, chamosite-lizardite }\end{array}$ \\
\hline Oxide-iron & Oxidation & Goethite rocks & $\begin{array}{l}\text { Goethite, } \\
\text { quartz goethite, clinochloro goethite }\end{array}$ \\
\hline Nontronite & Hydration & Nontronite rocks & Nontronite, talc-chlorite-nontronite \\
\hline \multirow[t]{2}{*}{ Serpentinite } & Leaching & Lysardite rocks & $\begin{array}{l}\text { Clinochlore-talk-lizardite, nepuite-quartz- } \\
\text { lizardite, clinochlore-pennine lizardite }\end{array}$ \\
\hline & Disintegration & Chrysotile rocks & $\begin{array}{l}\text { Clinochlore-chrysotile, talc-chrysotile, dia- } \\
\text { bantite-brunsvigite-picnochlore-chrysotile }\end{array}$ \\
\hline
\end{tabular}

2020). Despite this fact, the authors have compiled a detailed genetic classification of weathering crust minerals and hyperbasites (Table 2). Moreover, the sequence of mineral formation was noted (Table 3).

In the presented genetic classification all minerals of the weathering crust of hyperbasites of the Serovsko-Maukski ophiolite belt are divided into endogenous and exogenous (Ilalova, 2019). Four groups are distinguished among the endogenous ones: magmatogenic-relict 
Table 2. Genetic classification of the basic minerals of the weathering crust of the hyperbasites of the Serovsko-Maukski ophiolite belt.

\begin{tabular}{|c|c|c|c|}
\hline \multicolumn{4}{|l|}{ Endogenous } \\
\hline Magmatogenic-relict minerals & $\begin{array}{l}\text { Oceanic weathering } \\
\text { minerals }\end{array}$ & $\begin{array}{l}\text { Low-grade meta- } \\
\text { morphogenic-relict }\end{array}$ & $\begin{array}{l}\text { Hydrothermal relict } \\
\text { minerals }\end{array}$ \\
\hline $\begin{array}{l}\text { Olivine, pyroxene, } \\
\text { chromspinelide }\end{array}$ & $\begin{array}{l}\text { Lysardite, chrysotile, } \\
\text { pecoraite, amphibole, } \\
\text { bastis, magnetite }\end{array}$ & Chlorite, talc & $\begin{array}{l}\text { Millerite, pyrite, chal- } \\
\text { copyrite, pyrrhotite, } \\
\text { chlorite, talc }\end{array}$ \\
\hline \multicolumn{4}{|l|}{ Exogenous } \\
\hline \multicolumn{4}{|l|}{ Residual } \\
\hline Diffusion & Infiltration & \multirow{2}{*}{\multicolumn{2}{|c|}{$\begin{array}{l}\text { Infiltration-overlay minerals } \\
\text { Shamosite, siderite, rhodochrosite, pyrite }\end{array}$}} \\
\hline $\begin{array}{l}\text { Nontronite, montmorillonite, } \\
\text { hydrochlorite, halloysite, } \\
\text { kaolinite }\end{array}$ & $\begin{array}{l}\text { Goethite, hydrogetite, } \\
\text { hematite, nontronite, } \\
\text { talc, quartz, opal, chal- } \\
\text { cedony, calcite, mag- } \\
\text { nesite, dolomite, } \\
\text { hydrargillite }\end{array}$ & & \\
\hline
\end{tabular}

Table 3. Genetic classification of the basic minerals of the weathering crust of the hyperbasites of the Serovsko-Maukski ophiolite belt.

\begin{tabular}{|c|c|c|c|c|}
\hline \multirow{2}{*}{$\begin{array}{l}\text { Minerals of the } \\
\text { hyperbasites }\end{array}$} & \multicolumn{4}{|c|}{ Profile zones of the weathering crust } \\
\hline & Disintegration & Leaching & Nontronite & Ochre \\
\hline Olivine & \multirow{2}{*}{\multicolumn{2}{|c|}{$\begin{array}{l}\text { Iron hydroxides } \\
\text { Initial stage of nontronite formation }\end{array}$}} & Nontronite & Iron hydroxides \\
\hline Serpentine & & & & $\begin{array}{l}\text { Nontronite } \\
\text { Quartz, chalcedony, opal } \\
\text { Oxides and hydroxides of } \\
\text { iron }\end{array}$ \\
\hline \multirow[t]{2}{*}{ Chlorite } & Hydrochlorite & & $\begin{array}{l}\text { Hydro } \\
\text { mica }\end{array}$ & $\begin{array}{l}\text { Kaolinite, quartz, chal- } \\
\text { cedony, opal }\end{array}$ \\
\hline & Hydrochlorite & $\begin{array}{l}\text { Montmorillonite, } \\
\text { halloysite, kaolinite }\end{array}$ & & $\begin{array}{l}\text { Hydrargillite, iron } \\
\text { hydroxides }\end{array}$ \\
\hline Piroxene & Hydrated piroxene & & Nontronite & $\begin{array}{l}\text { Iron hydroxides, silica } \\
\text { minerals }\end{array}$ \\
\hline Amphibole & Hydrochlorite & Montmorillonite & & $\begin{array}{l}\text { Kaolinite, iron hydrox- } \\
\text { ides, hydrargillite }\end{array}$ \\
\hline Bastite & $\begin{array}{l}\text { Hydrated } \\
\text { bastite }\end{array}$ & & Nontronite & $\begin{array}{l}\text { Iron hydroxides, silica } \\
\text { minerals }\end{array}$ \\
\hline Magnetite & Maghemit, hematite & & & Iron hydroxides \\
\hline Chromspinelids & Magnetite & Hematite & & Iron hydroxides \\
\hline
\end{tabular}

Note. The table does not include minerals of infiltration-overlaid genesis.

minerals, minerals of oceanic weathering, low-grade metamorphogenic and hydrothermal relict minerals; among the exogenous ones - residual and infiltration-overlay minerals. Residual minerals are divided into two subgroups - diffusion and infiltration minerals.

The following rock-forming minerals of hyperbasites are referred to as magmatogenicrelict minerals: olivine, pyroxene and chromspinelide. Minerals of oceanic weathering (at the spreading stage) are chrysotile, lysardite, pecoraite, bastite, amphiboles and magnetite. Olivine is transformed into serpentine, pyroxene into bastite and chromspinelide into 
magnetite. Chromspinelide and magnetite are found in all areas of the crust, and in the ochre zone, compared to the lower zones, the content of magnetite and chromspinelide is much higher. Low-grade metamorphogenic-relict minerals are formed at low-grade metamorphism of the hyperbasites at the stage of early Mesozoic tectonic-magmatic activation of the region, which appeared as a result of transregional riftogenesis and trap magmatism (Rapoport, 1998; Spiridonov, 2008). Serpentine, bastite, amphibole forms chlorite and talc. Chlorite in the weathering crust by composition belongs mainly to the ironmagnesia series. At microscopic study of thin section from zones of disintegration and leaching full or partial replacement of serpentine, bastite, amphiboles by chlorite is clearly visible. Talc forms pseudomorphoses over the chlorite and other earlier minerals. Iron, released from olivine and pyroxene, forms in serpentinite thin rash or chain-shaped clusters of tiny grains of magnetite. Hydrothermal relict minerals found in the cracks of chrysotile-lysardite metasomatites from the zone of disintegrated serpentinite, are formed in hydrothermal processes. Low-temperature hydrothermal solutions separated from the magmatic hearth and containing copper, nickel, iron and sulphur have deposited sulfide minerals such as pyrite, millerite, chalcopyrite and pyrrhotite in the tectonically disturbed serpentinite zones. Since these minerals are localized in the cracks of disintegrated serpentinite, their formation due to the serpentinization process is excluded. Chalcopyrite, pyrite, pirrotine in the form of grains up to $1 \mathrm{~mm}$ in irregular and cubic shape are associated with millerites, which have the form of needle crystals, often collected in radialbeam aggregates. In the ochre zone, sulfide minerals are hardly preserved, except for pyrite, which is formed here by infiltration. These sulfides quite often contain nickel, which is reflected in their chemical compositions.

Thus, at this stage, the transformation of relict minerals and the formation of new minerals occurring during low-grade metamorphism and hydrothermal processes are being completed. Subsequent transformations of minerals are the result of exogenous processes.

Residual minerals can occur in two ways:

1) as a result of direct metasomatic substitution of serpentinites during their weathering (diffusion);

2) as a result of deposition of cold solutions during their infiltration into the depths of tectonic disturbance zones and cracks in serpentinite (infiltration).

Depending on this, the residual minerals are subdivided into diffusion and infiltration minerals. Often the same mineral can be formed in different ways. Nontronite, montmorillonite, hydrochlorite, halloysite, and kaolinite are classified as diffusion residual minerals. Serpentine, being exposed to weathering agents (oxygen, carbon dioxide, humus acids and ground water) undergoes a complex successive process of changes. Weathering of serpentine minerals occurs under conditions of humid climate and strong cracking of rocks. In the disintegration zone, serpentine, absorbing water moving through the cracks or rock pores, begins to hydrate and partially turn into nontronite. Further removal of cations from serpentine minerals leads to destruction of the crystal lattice, reduction of volume weight, increase of porosity and change of other physical and optical properties, in particular the refractive index. If relict olivine remains in serpentinite, then in the disintegration zone, mainly in its upper part, it is destroyed with the formation of a residual grid, consisting of brown iron hydroxides.

Piroxene and amphibole in the upper horizons of the disintegration zone and in the lower horizons of the leaching zone turn into hydrogetite (as a fine mesh) and nontronite. Under the microscope it can be seen that this process begins with microcracks and gradually spreads to all grains.

There are several ways of chlorite weathering in the weathering crust, but the end products of their decomposition are the same minerals: halloysite, kaolinite and iron hydroxides (Lazarenkov et al., 2011; Ilalova et al., 2018). The stage of chlorite change can be represented by the following schemes: 
1. Chlorite $\rightarrow$ hydrochlorite $\rightarrow$ hydromica $\rightarrow$ halloysite $\rightarrow$ kaolinite $\rightarrow$

$\rightarrow$ quartz, opal, chalcedony

$\rightarrow$ iron hydroxides

$\rightarrow$ hydrargillite

2. Chlorite $\rightarrow$ hydrochlorite $\rightarrow$ montmorillonite $\rightarrow$ halloysite $\rightarrow$ kaolinite $\rightarrow$

$\rightarrow$ hydrargillite $\rightarrow$ iron hydroxides

During weathering, chlorite is converted to hydrochlorite, which is particularly characteristic of the upper crust areas of the weathering. Hydrochlorite under a microscope is usually observed as scaly grains or earthy masses of green, pale green color. During weathering of chlorite there is oxidation of $\mathrm{FeO}$ and hydrolysis of silicate, accompanied by silica release, and partial removal of $\mathrm{MgO}$. During $\mathrm{MgO}$ leaching, the coloration of the mineral turns pale and the refractive index decreases. If there are high concentrations of nickel in descending waters, it replaces $\mathrm{Mg}^{2+}$ and $\mathrm{Fe}^{2+}$ equivalent. Montmorillonite, in turn, decomposes to form kaolinite or halloysite and iron hydroxides.

Magnetite, maghemite and hematite occur as a result of oxidation of magmatogenic-relict chromspinelids, magnetite. Change of chromspinelids begins at the periphery of grains, then spreads through cracks, gradually covering the entire area of the grain. Magnetite formed during oceanic weathering (at the stage of spreading) during subsequent weathering also turns into magnetite, then into hematite.

Infiltration-resistant minerals are the most interesting and numerous. Goethite, hydrogethyte, hematite are formed as a result of the release of iron from iron-containing minerals at their destruction in various zones of the weathering crust. Thus, when magnetite, maghemite and other iron-containing minerals change further, iron is transferred from the crystal lattice to cold solutions as a result of the release of these minerals. These solutions seep into the loose ochre mass of the upper crust zone and move along the cracks of leached and disintegrated serpentinite and as the corresponding concentrations are reached, iron falls out of the solutions in the form of goethite, hydrogetite and hematite. When other chemical elements, such as $\mathrm{Mg}, \mathrm{Al}, \mathrm{Si}$ and $\mathrm{Ni}$, were introduced into the solutions together with iron, the formation of nontronite occurred.

Silicon entering the crust solutions due to the destruction of diorite minerals was used to form sedimentary quartz, chalcedony and opal. Some part of silicon precipitated together with magnesium, iron, aluminum and sometimes nickel to form talc, nontronite and other minerals. Calcite, magnesite and dolomite, as well as other minerals of this group, are sediment-newly formed. Magnesium and calcium were introduced into crust solutions as a result of plagioclases and pyroxenes destruction from dikes, serpentine and chlorites. Carbonate minerals were mostly precipitated in cracks of disintegrated and leached serpentinite, where $\mathrm{pH}>11$ and environment was reductive.

Infiltration-overlay minerals appeared after the formation of the weathering crust and its overlapping by precipitation from the Jurassic and Cretaceous periods. They are not connected with the destruction of hyperbasite massifs and dike rocks. Mineralized waters from lake and marsh water bodies penetrated downwards (into the upper zones of the weathering crust) and as a result of infiltration and overlaying replaced some previously formed minerals. In addition to metasomatic substitution, the minerals of this group were precipitated from cold solutions of cracks and rocks in the weathering crust. Infiltration-metasomatic chamosite was found in the weathering crust of serpentinite, which partially replaced both exogenous newly formed and endogenous relic minerals. Infiltration chamosite is distinguished by cracks and voids and belongs to the later generation. This group also includes pyrite, siderite and rhodochrosite. Pyritization and sideritization as infiltrationally superimposed processes are weaker in the weathering crust than chamositization. Pyrite in the form of crystals $0.5 \mathrm{~mm}$ in size is often found in the ochreous hydrogethyte mass of the upper area of the weathering crust. Siderite is in close paragenetic association with chamosite, rhodochrosite. It is observed in the form of rounded spherolite grains and clear crystalline aggregates in loose clayey chamosite rocks, cementing them. 


\section{CONCLUSIONS}

The sequence of mineral formation in the weathering crust does not have to be a fully developing process with inevitable and always defined transition minerals. It depends on physical and chemical conditions of the environment. Under favorable conditions this process occurs very quickly, in adverse conditions - slowly or even stops at some stage, not giving "final" products of rock decomposition. The "final" products are minerals resistant in the uppermost horizons of the weathering crust; most often these are hydro-oxides and oxides of iron, quartz, opal.

Thus, the weathering crust of the hyperbasite massifs of the Serovsko-Maukski ophiolite belt contains a large number of minerals of various genesis and carries the traces of various processes - oceanic weathering, low-grade metamorphism, hydrothermal and metasomatic processes. The obtained results allowed the authors provide evidence of the appearance of hydrothermal processes and lowgrade metamorphism in the history of development of massifs and weathering crust of the Serovsko-Maukski ophiolite belt.

The particular importance of this study is that the obtained knowledge allows reconstructing the processes of redistribution and accumulation of ore components in the weathering crust rocks, in particular, the results can be used in forecasting estimates of the territory for nickel.

It should be noted that rich nickel-rich weathering crusts occur due to overlapping processes of endogenous, thermal and eluvial origin (otherwise - a combination of hypergenic and hypogenic factors), which results in the formation of polychronous and polygenic formations. This suggests that surface eluvial formations can continue to the depth, especially in the zones of faults, contacts of intrusive bodies, wide development of dyke complex rocks and other tectonically weakened zones. Comprehensive geological data analysis shows that such deposits can be found on poorly studied areas of overlapping serpentinite melange of deep faults with a platform cover, in particular in the fracture zones framing the Tagilo-Magnitogorsky deflection and the East Ural Rise.

The study was performed as part of the Joint German-Russian Project No 20-55-12002 of the Russian Foundation for Basic Research.

\section{REFERENCES}

Aleksandrova, T.N., Talovina, I.V., Duryagina, A.M. 2019. Gold-sulphide deposits of the Russian Arctic zone: Mineralogical features and prospects of ore benefication. Chemie der Erde (144). DOI: 10.1016/j.chemer.2019.04.006.

ElDeeb A.B., Brichkin V.N., Kurtenkov R.V., Bormotov I.S. 2019. Extraction of alumina from kaolin by a combination of pyro- and hydro-metallurgical processes. Applied Clay Science (172): $146-154$.

Ilalova R. K. 2019. Geological structure, composition and conditions of formation of nickel-bared weathering crust of hyperbasites of the eastern slope of the Northern Ural: dissertation [Geologicheskoe stroenie, sostav i usloviya formirovaniya nikelenosnoj kory vyvetrivaniya: dis. . . kand. geol.-min. nauk], St. Petersburg: 173 p.

Ilalova R. K. \& Gulbin Y. L. 2018. Thermometry of nickel chlorites of the Kolskii massif (the Northern Urals). Proceedings of RMS (147): 1-17.

Lazarenkov V.G., Talovina I.V., Vorontsova N.I., Mezentseva O.P. \& Ryzhkova S.O. 2011. Nickel chlorites of oxide-silicate nickel deposits of the Urals. Lithology and mineral resources (3): 1-10.

Litvinenko V.S. 2020. Digital Economy as a Factor in the Technological Development of the Mineral Sector. Natural Resources Research (29): 1521-1541.

Mezenceva O. P. \& Talovina I. V. 2011. The value of ${ }^{\delta 34}$ S in millerite and the genesis of chamosite nickel ores of the Elovsky deposit, the Northern Ural. Journal of Mining Institute (189): 58-61.

Popov O., Talovina I., Lieberwirth H., Duryagina A. 2020. Quantitative microstructural analysis and x-ray computed tomography of ores and rocks - comparison of results. Minerals 10 (2),129. https:// doi.org/10.3390/min10020129.

Talovina I. V., Lazarenkov V. G., U. Kempe, Voroncova N. I., Mezenceva O. P., Ryzhkova S. O. \& Ugolkov V. L. 2010. Nickel serpentines of the lysardite - nepuit and karyopilite series in hypergene nickel deposits of the Urals. Proceedings of RMS (4): 80-94. 
Spiridonov E. M. 2008. In development of the idea of F.V. Chukhrova about late hydrothermal formations: low-grade metamorphism as ore preparation, ore-forming and ore-transforming processes. Institute of Geology of Ore Deposits, Petrography, Mineralogy and Geochemistry RAS: 206-209.

Stepanov S. Y., Palamarchuk R. S., Kozlov A. V., Khanin D. A., Varlamov D. A., Kiseleva D. V. 2019. Platinum-group minerals of Pt-placer deposits associated with the svetloborsky Ural-Alaskan type massif, middle urals, Russia. Minerals 9(2). https://doi.org/10.3390/min9020077.

Voroncova N. I., Talovina I. V., Lazarenkov V. G., Gajfutdinova A. M. \& Tihomirova M. 2013. ${ }^{87} \mathrm{Sr} /{ }^{86} \mathrm{Sr}$ isotopic ratios in the rocks and ores of the Sakharin and Ufaleysky hypergene nickel deposits of the Urals. Journal of Mining Institute (200): 179-185.

Zubov V.P. 2017. Status and directions of improvement of development systems of coal seams onperspective kuzbass coal mines. Journal of Mining Institute (225): 292-297. 